\title{
Penerapan Penyusunan Laporan Keuangan pada UMKM Berbasis SAK EMKM
}

\section{Rizky Aminatul Mutiah*}

Jurusan Akuntansi, Fakultas Ekonomi, Universitas Muhammadiyah Jember, Jawa Timur, Indonesia

\author{
A R T I C L E I N F O \\ Article history: \\ Received 19 May 2019 \\ Received in revised form \\ 16 June 2019 \\ Accepted 15 July 2019 \\ Available online 26 August \\ 2019 \\ Kata Kunci: \\ UMKM, Laporan Keuangan, \\ SAK EMKM \\ Keywords: \\ UMKM, Financial \\ Statements, SAK EMKM
}

\section{A B S T R A K}

Laporan keuangan hanyalah informasi tentang keuangan di perusahaan yang dapat digunakan untuk melihat kondisi perusahaan dan menilai kinerja perusahaan dalam periode tertentu. Dalam siklus akuntansi satu periode dapat ditentukan sesuai dengan kebutuhan harian, mingguan, bulanan, triwulanan, empat bulan, enam bulan, atau setahun sekali. Penelitian ini bertujuan untuk memudahkan pemain UMKM dalam menyusun laporan keuangan yang sesuai dengan standar yang telah berlaku pada 1 Januari 2018. Penelitian ini diperlihatkan kepada UMKM Silky Parijatah yang belum menyusun laporan keuangan sesuai dengan SAK EMKM. Penelitian ini menggunakan metode deskriptif kualitatif, yang merupakan studi kasus. untuk pengambilan data dilakukan dengan observasi, wawancara, dan dokumentasi. Penelitian ini dilakukan untuk mengidentifikasi kendala yang terjadi pada UMKM Silky parijatah dan untuk menyusun laporan keuangan sesuai dengan standar EMKM IFRS yang berlaku. Hasil penelitian ini menunjukkan bahwa UMKM memiliki masalah dalam menyusun laporan keuangan, yaitu terbatasnya pemikiran tentang mengelola laporan keuangan dan terbatasnya jumlah Sumber Daya Manusia (SDM) yang tidak memadai dalam menyusun laporan keuangan. Laporan keuangan berdasarkan EMKM SAK, yaitu Laporan Posisi Keuangan, Laporan Laba Rugi, dan Catatan atas Laporan Keuangan.

\section{A B S T R A C T}

Financial statements are simply information about finance in companies that can be used to see a company's condition and assess the company's performance in a certain period. In the accounting cycle one period can be determined according to the needs of daily, weekly, monthly, quarterly, four months, six months, or once a year. This study aimed to facilitate UMKM players in preparing financial statements that in accordance with the standards that have been effective on 1 January 2018. This research was show to UMKM Silky Parijatah who have not prepared financial reports in accordance with SAK EMKM. This study uses a qualitative descriptive method, which is a case study. The data carried out by observation, interviews, and documentation. This research carried out to identify the obstacles that have occurred in Silky parijatah UMKM and to compile financial reports in accordance with applicable standards of EMKM IFRSs. The results of this study indicate that UMKM have problems in preparing financial statements, the limited thinking about managing financial statements and the limited number of Human Resources (HR) that are inadequate in preparing financial statements. Financial statements based on EMKM SAK, namely Financial Position Reports, Profit and Loss Statements, and Notes to Financial Statements.

\footnotetext{
* Corresponding author.

E-mail addresses: mutiahra@gmail.com (Rizky Aminatul Mutiah)
} 


\section{Pendahuluan}

Perencanaan pembangunan (development planning) adalah suatu bentuk perencanaan yang berkaitan dengan upaya meningkatkan pertumbuhan tingkat ekonomi dan kesejahteraan masyarakat (Hariyono, 2010). Tidak dapat dipungkiri, Indonesia sebagai negara yang sedang berkembang tidakdapat terlepas dari kegiatan perencanaan pembangunan. Dari masa ke masa, ternyata Negara Indonesia telah mengalami perubahan paradigma dalam perencanaan pembangunan.Setidaknya sejak dimulainya era reformasi, paradigma perencanaan pembangunanberganti dari perencanaan komprehensif menjadi perencanaan strategis. Paradigma perencanaan strategis dipilih oleh pemerintah karena dirasa memiliki manfaat yang jelas dalam jangka waktu yang singkat (Hariyono, 2010). Menurut Putra (2016) Semakin maju suatu Negara semakin banyak orang yang terdidik, dan banyak pula orang menganggur, maka semakin dirasakan pentingnya dunia wirausaha. Pembangunan akan lebih mantap jika ditunjang oleh wirausahawan karena kemampuan pemerintah sangat terbatas. Pemerintah tidak akan mampu menggarap semua aspek pembangunan karena sangat banyak membutuhkan anggaran belanja, personalia, dan pengawasannya. Oleh sebab itu, wirausaha merupakan potensi pembangunan, baik dalam jumlah maupun dalam mutu wirausaha itu sendiri. Dengan ada niat atau keinginan untuk berwirausaha akan menjadi sebuah loncatan setidaknya sebagai sebuah harapan terwujudnya pemerataan pembangunan dan kesejahteraan masyarakat. Banyak faktor psikologis yang membentuk sikap negatifmasyarakat sehingga mereka kurang berminat terhadap profesi wirausaha, antara lain sifat agresif, ekspansif, bersaing, egois, tidak jujur, kikir, sumber penghasilan tidak stabil, kurang terhormat, pekerjaan rendah, dan sebagainya. Pandangan semacam ini dianut oleh sebagian besar penduduk, sehingga mereka tidak tertarik. Tidak seperti layaknya etnis Cina yang terkenal sebagai wirausahawan yang rajin dan terampil, tetapi itu tidak menjadi sebuah patokan bahwa orang pribumi atau orang Indonesia tidak memiliki keterampilan hanya saja orang Indonesia tidak berani mengambil resiko dalam berdagang, terutama pada zaman sekarang ini zaman semakin maju kita dituntut untuk selalu kreatif dan inovatif tetapi kurang kesadaran tersebut menyebab Indonesia tertinggal dengan negara-negara dalam hal perekonomian negara. Paradigma perencanaan strategis yang dianut oleh pemerintah dalam kegiatan perencanaan pembangunan daerah memiliki nilai lebih dengan adanya pelibatan stakeholders (para pemangku kepentingan) yang menjadikan perencanaan pembangunan daerah menjadi tepat sasaran. Dengan kelebihan tersebut, makastakeholdersdapatberperan aktif dalam proses penyusunan rencana pembangunan daerah di wilayahnya masing-masing, sehingga perencanaan pembangunan daerah berlangsung secara partisipatif. Berkembangnya perekonomian di seluruh Indonesia ditandai dengan banyaknya usaha yang telah berdiri diberbagai bidang, salah satunya menumbuh - kembangkan UMKM tersebut. Usaha Mikro Kecil dan Menengah merupakan salah satu usaha yang memberikan peran penting dalam pertumbuhan ekonomi di Indonesia karena dengan adanya Usaha Mikro Kecil dan Menengah (UMKM) dapat membuka peluang pekerjaan bagi masyarakat untuk meningkatkan pendapatan masyarakat dan mengurangi jumlah pengangguran di seluruh Indonesia. karena Indonesia ini merupakan negara maju dan berkembang maka sangat dibutuhkan adanya perubahan perekonomian diseluruh indonesia. Menurut Suci (2017) Semua keberhasilan yang telah dicapai oleh memiliki titik kelemahan yang harus segera diselesaikan untuk dicarikan solusi yang terbaik. Kelemahan yang dihadapi oleh para pengusaha UMKM dalam meningkatkan kemampuan usaha sangat kompleks dan meliputi berbagai indikator yang mana salah satu dengan yang lainnya saling berkaitan antara lain; kurangnya permodalan baik jumlah maupun sumbernya, kurangnya kemam puan manajerial dan keterampilan beroperasi dalam mengorganisir dan terbatasnya pemasaran.

Dalam mendirikan suatu perusahaan memiliki tujuan untuk menghasilkan suatu laba yang maksimal dari setiap transaksi, sehingga perusahaan harus mempertahankan dan tetap menjaga kelangsungan perusahaan. Semakin meningkatnya suatu laba perusahaan maka perusahaan tersebut dapat dinyatakan mengalami perkembangan dalam usaha yang telah didirikan. Sehingga informasi tentang laporan keuangan sangat dibutuhkan dan penting bagi perusahaan dalam pengambilan keputusan.

Laporan keuangan merupakan suatu informasi yang diberikan kepada penggunanya yang berkaitan dengan kondisi perusahaan dan tujuannya itu untuk mendeskripsikan keadaan perusahaan dan pengambilan keputusan. Tetapi dengan adanya laporan keuangan belum tentu seutuhnya bisa menilai seluruh kinerja perusahaan, harus ada analisis pada laporan keuangan yang baik dan tepat. Karena dari setiap usaha yang telah didirikan memiliki prinsip untuk mencapai tujuan tertentu, dimana prinsip dari setiap didirikannya suatu usaha umumnya mempunyai tujuan yang sama, hanya yang membedakan pada perioritasnya. Menurut Riswan (2014) Kinerja keuangan merupakan gambaran setiap hasil ekonomi yang mampu di raih oleh perusahaan pada periode tertentu melalui aktivitas-aktivitas perusahaan untuk menghasilkan keuntungan secara efektif dan efisien. Kinerja keuangan perusahaan dapat di ukur dengan 
menganalisa dan mengevaluasi laporan keuangan. Informasi posisi keuangan dan kinerja keuangan digunakan sebagai dasar untuk memprediksi posisi keuangan dan kinerja di masa depan. Informasi yang tersaji di dalam laporan keuangan memberikan gambaran mengenai kondisi dan kinerja keuangan perusahaan dalam satu periode.

Suatu perusahaan dapat dikatakan efektif dan efisien apabila perusahaan tersebut sudah menerapkan penyusunan laporan keuangan yang sudah sesuai dengan prosedur dan langkah yang telah ditetapkan dalam akuntansi. Jika Kegiatan operasional perusahaan itu berkembang dan kompleks maka diperlukannya penyusunan laporan keuangan untuk diterapkan diperusahaan tersebut. Dalam penyusunan laporan keuangan bisa dikatakan mempunyai hasil apabila informasi tersebut bisa digunakan untuk menunjukkan suatu kondisi keuangan pada perusahaan (Suhairi, 2012).

Laporan keuangan secara sederhana merupakan suatu informasi mengenai keuangan pada perusahaan yang bisa digunakan untuk melihat suatu kondisi perusahaan dan menilai kinerja perusahaan dalam suatu periode tertentu. Dalam siklus akuntansi satu periode itu dapat ditentukan sesuai dengan kebutuhan. Bisa untuk harian, mingguan, bulanan, per tiga bulan, per empat bulan, per enam bulan, atau satu kali dalam satu tahun.

Menurut Sulistyo (2010) UKM adalah salah satu jenis usaha milik perorangan, badan usahanya berbadan hukum atau tidak berbadan hukum. Badan usaha ini selain berdiri sendiri dan bukan merupakan anak perusahaan atau cabang perusahaan yang dimiliki, dikuasai atau berafiliasi baik langsung maupun tidak langsung. Peran Usaha Mikro Kecil dan Menengah ini sangatlah penting, sehingga harus diperhatikan cara untuk meningkatkan kinerja di UMKM tersebut yaitu melalui laporan keuangan, yang menjadi masalah utama dalam mengembangkan usaha tersebut adalah mengenai pengelolaan keuangan. Para pelaku UMKM belum sadar akan pentingnya laporan keuangan disuatu perusahaan karena keterbatasan informasi dan pengetahuan tentang akuntansi sangat terbatas. Hal seperti ini berkaitan dengan latar belakang pendidikan para Sumber Daya Manusia (SDM) di UMKM tersebut. untuk menggambarkan kinerja perusahaan yang baik maka diperlukannya laporan keuangan yang relevan dan handal. Serta dengan adanya laporan keuangan dapat digunakan sebagai alat pendukung UMKM dalam pengajuan kredit di Bank. Menurut Arliman (2017) Peran UMKM memiliki nilai strategis dalam memperkokoh perekonomian nasional (ekonomi rakyat) maka selayaknya pemerintah memberi perhatan yang layak (strategi dan kebijakan) bagi pemberdayaan (prioritas dan pemihakan), yaitu dipandang sebagai suatu kelompok unit usaha yang seharusnya terintegrasi dalam dunia usaha secara nasional yang nantnya dapat meningkatkan tarif hidup dan daya saingnya. UMKM sebagai cikal bakal kewirausahaan yang berproses, perlu diberi perhatan yang lebih seksama dari berbagai aspek.

Saat ini UMKM dinilai mampu berkontribusi hingga 99\% bagi perkembangan ekonomi Indonesia yang pada tahun lalu mampu mencatat pertumbuhan sebesar 6,2\%. Hampir 99\% UMKM mendominasi pertumbuhan ekonomi Indonesia, hanya 1\% dalam bentuk usaha besar. UMKM merupakan satu sektor yang mampu bertahan dalam situasi ekonomi global yang sedang tertekan. Sektor UMKM juga mampu menyerap tenaga kerja yang cukup signifikan. Sektor UMKM mampu menyumbang sekitar $56 \%$ pada produk domestik bruto dan UMKM dapat menyerap tenaga kerja sebanyak 97\%. Pada awal tahun 2012, jumlah pekerja di sektor UMKM tercatat hamper 80 juta orang, dari jumlah tersebut sebanyak 70,3 juta diantaranya bekerja di sektor usaha kecil dan sisanya di sector usaha menengah. Begitu besarnya peran UMKM dalam perekonomian nasional, maka perlu adanya perhatian untuk mendorong kelangsungan hidupnya. (Bahtiar Rifai, 2013) UMKM yang selama ini kurang diperhatikan justru mampu bertahan dalam kondisi krisis. Hal ini menunjukkan bahwa sektor UMKM merupakan pilar utama perekonomian Indonesia pada masa krisis. Karena itu tidak berlebihan jika perhatian diarahkan pada UMKM. Karena UMKM memiliki daya survival yang tinggi dan mampu bertahan hidup di tengah berbagai kesulitan serta keterbatasan. Dalam hal ini, UMKM dengan caranya sendiri mampu mengatasi banyak masalah secara lebih dinamis dalam menghadapi perkembangan pasar (Agus Martowardoyo, 2013) Ditengah arus perubahan lingkungan bisnis yang makin intens, UMKM dituntut untuk memiliki daya adaptasi dan responsi yang makin tinggi. Tanpa kemampuan untuk melakukannya UMKM beresiko tidak dapat berlangsung hidup karena perubahan arus globalisasi dan tingginya persaingan membuat UMKM harus mampu menghadapi tantangan global, seperti meningkatkan inovasi produk dan jasa, pengembangan sumber daya manusia dan teknologi, serta perluasan area pemasaran. Hal ini perlu dilakukan untuk menambah nilai jual UMKM itu sendiri, utamanya agar dapat bersaing dengan produk-produk asing yang kian membanjiri sentra industri dan manufaktur di Indonesia, mengingat UMKM adalah sektor ekonomi yang mampu menyerap tenaga kerja terbesar di Indonesia (Sudaryanto,2011). Keterbatasan UMKM disebabkan karena kurangnya pengetahuan tentang informasi akuntansi akan menjadikan lemahnya pelaku Usaha Mikro Kecil dan Menengah (UMKM) dan akan mengakibatkan sulitnya UMKM untuk memperoleh pembiayaan/kredit di bank, sedangkan lembaga intermediasi keuangan sangat menunjang dan banyak upaya untuk permodalan bagi UMKM. Kondisi yang seperti ini tentunya mempersulit Para 
UMKM dalam meningkatkan kapasitas usaha serta untuk mengembangkan usahanya ke pangsa pasar. Faktor utama perbankan sulit mencairkan kredit kepada UMKM karena risiko tinggi yang diterima perbankkan dan sulitnya dalam mencari data formal seperti laporan keuangan. Untuk itu pelaku UMKM diharuskan untuk melakukan penyusunan laporan keuangan yang sesuai standar dan terstruktur yang berlaku, agar laporan keuangan tersebut dapat dipahami serta dimengerti oleh pemilik atau pihak lain seperti kreditur.

Terkait dengan kondisi diatas, untuk mempermudah UMKM dalam penyusunan laporan keuangan, Ikatan Akuntansi Indonesia (IAI) telah menerbitkan SAK EMKM yaitu standar akuntansi keuangan untuk Entitas Mikro Kecil dan Menengah pada tanggal 24 Oktober 2016 dan berlaku secara efektif 1 januari 2018. Diterbitkannya SAK EMKM bertujuan untuk membantu para pelaku UMKM di seluruh indonesia dalam mengimplementasikan laporan keuangan agar pelaku UMKM dengan mudah untuk mendapatkan pendanaan keberbagai lembaga keuangan (SAK EMKM, 2016).

Silky Parijatah merupakan suatu perusahaan yang bergerak dibidang perdagangan yang menjual berbagai macam kebutuhan sandang dan pangan dengan skala pemasaran yang cukup luas dan dijalankan oleh bapak Edy Yusuf sejak 10 tahun dan didirikan pada tanggal Rabu, 9 September 2009 yang berlokasi di Jl. Parijatah Wetan, Patirejo, Srono Kabupaten Banyuwangi. Mengingat akan kebutuhan sandang dan pangan banyak pelaku pasar dengan berbagai macam jumlah omset yang didapatkan dalam penjualan tersebut. KhususnyaInformasi dari pemilik Silky Parijatah untuk omset pertahunnya mengalami kenaikan sebesar Rp 425.000.000 dapat dilihat dari tahun 2017 sebesar Rp 3.171.201.000 dan pada tahun 2018 sebesar Rp 3.596.201.000 akan tetapi pemilik merasa kesulitan dalam membuat laporan keuangan. Dikarenakan keterbatasan pemikiran mengenai pengelolaan laporan keuangan serta terbatasnya sumber daya manusia yang kurang memadai dalam menyusun laporan keuangan, dengan demikian perusahaan tidak terkontrol dengan baik, maka peneliti mendapatkan ide untuk menerapkan penyusunan laporan keuangan pada Silky Parijatah sesuai dengan standar yang berlaku yaitu SAK EMKM, karena SAK EMKM mulai berlaku secara efektif pada tanggal 1 januari 2018. Sehingga penelitian ini menggunakan SAK EMKM karena lebih mudah dan praktis dibandingkan SAK ETAP. Penerapan laporan keuangan yang disusun oleh Silky Parijatah masih sangat sederhana yaitu hanya menghitung sebatas uang masuk dan uang keluar, bahkan dilihat dari sistem penggajian di Silky Parijatah masih menggunakan ingatan saja tanpa tertulis. Sehingga laporan keuangan yang diharapkan oleh pemilik Silky Parijatah bisa dijadikan sebagai evaluasi usaha serta digunakan sebagai dasar pengambilan keputusan.

Berdasarkan latar belakang diatas, dapat menarik kesimpulan bahwa laporan keuangan harus dimiliki dari setiap perusahaan sehingga dengan adanya SAK EMKM dapat mempermudah dalam penyusunan laporan keuangan. oleh karena itu, peneliti terdorong untuk melakukan penelitian dengan judul “Penerapan Penyusunan Laporan Keuangan Pada Umkm Berbasis Sak Emkm (Studi Kasus pada Silky Parijatah)".

\section{Metode}

A. Jenis Penelitian

Penelitian deskriptif kualitatif dengan metode study kasus.

B. Lokasi Penelitian

Penelitian ini dilakukan berdasarkan hasil observasi pada Silky Parijatah Srono, Banyuwangi dan beralamtkan di Jl. Patirejo Wetan Rt 03 Rw 01, Srono, Kabupaten Banyuwangi, Provinsi Jawa Timur.

C. Jenis dan Sumber Data

1) Data Primary

2) Data Secondary

D. Metode Pengumpulan Data

Observasation, interview, dokumentation

E. Metode Analisis Data

1) Identifikasi laporan keuangan pada Silky Parijatah.

2) Pengumpulan data atau bukti transaksi.

3) Penjurnalan.

4) Buku besar.

5) Neraca saldo.

6) Laporan keuangan meliputi

7) Lap. Posisi Keuangan

8) Lap L/R

9) Catatan Atas Laporan Keuangan (CALK) 


\section{Hasil dan pembahasan}

\section{A. Laporan Posisi Keuangan Silky Parijatah}

Tabel 1. Laporan Posisi Keuangan 2018

\begin{tabular}{lcc}
\hline ASSET & & \\
Cash & $\mathrm{Rp}$ & 1.085 .228 .000 \\
\hline Jumlah kas & $\mathbf{R p}$ & $\mathbf{1 . 0 8 5 . 2 2 8 . 0 0 0}$ \\
\hline Persediaan & $\mathrm{Rp}$ & 960.299 .000 \\
Tanah & $\mathrm{Rp}$ & 412.000 .000 \\
Bangunan & $\mathrm{Rp}$ & 606.000 .000 \\
Akum. penyusutan bangunan & $\mathrm{Rp}$ & $30.300 .000)$ \\
Kendaraan & $\mathrm{Rp}$ & 150.000 .000 \\
Akum. penyusutan kendaraan & $(\mathrm{Rp}$ & $18.750 .000)$ \\
Peralatan & $\mathrm{Rp}$ & 46.960 .000 \\
Akum. penyusutan peralatan & $(\mathrm{Rp}$ & $5.870 .000)$ \\
\hline JUMLAH ASSET & $\mathbf{R p}$ & $\mathbf{3 . 2 0 8 . 5 6 7 . 0 0 0}$ \\
\hline Liabilitas & & \\
$\quad$ Utang Usaha & $\mathrm{Rp}$ & 1.144 .809 .000 \\
\hline Jumlah Liabilitas & $\mathbf{R p}$ & $\mathbf{1 . 1 4 4 . 8 0 9 . 0 0 0}$ \\
\hline Ekuitas & \multicolumn{2}{|}{} \\
$\quad$ Modal & $\mathrm{Rp}$ & 1.846 .840 .000 \\
Saldo laba (defisit) & $\mathrm{Rp}$ & 216.918 .000 \\
\hline Jumlah Equity & $\mathbf{R p}$ & $\mathbf{2 . 0 6 3 . 7 5 8 . 0 0 0}$ \\
\hline JUMLAH LIABILITAS DAN EKUITAS & $\mathbf{R p}$ & $\mathbf{3 . 2 0 8 . 5 6 7 . 0 0 0}$ \\
\hline
\end{tabular}

\section{B. Laporan Laba Rugi Silky Parijatah}

Tabel 2. Laporan L/R 2018

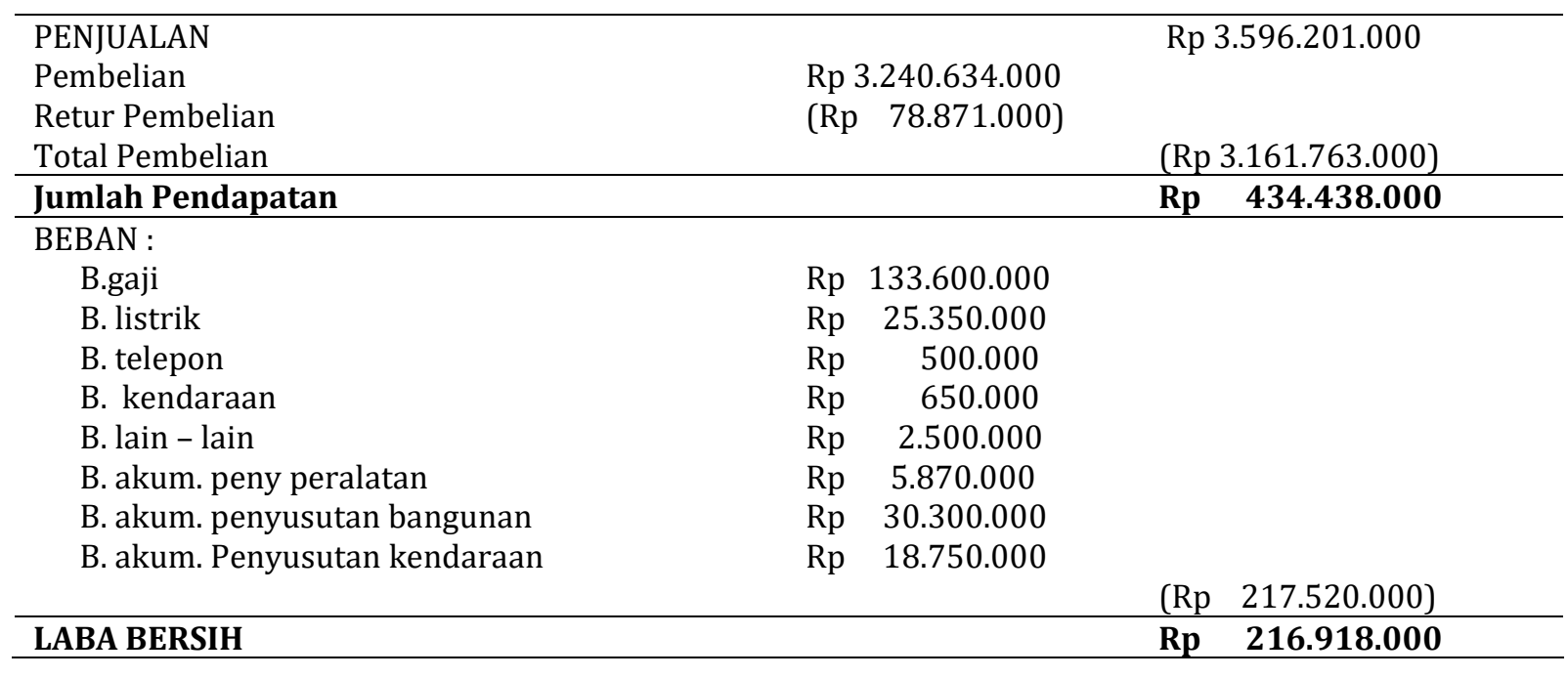

\section{Catatan Atas Laporan Keuangan (CALK)}

Didalam CALK ini berisi tentang suatu informasi tambahan serta rincian yang telah disajikan tergantung pd jenis kegiatan usaha yang telah dilakukan dan Catatan atas laporan keuangan disajikan secara sistematis dan praktis. Untuk setiap pos dalam laporan keuangan merujuk silang ke informasi yang terkait dalam catatan atas laporan keuangan (SAK EMKM, 2016). Silky Parijatah belum menerapkan laporan keuangan yang sesuai dengan standarnya yaitu SAK EMKM. 


\section{Simpulan dan saran}

Pencatatan di Silky Parijatah masih sangat sederhana yaitu hanya mencatat pembelian dan pencatatan penjualan Silky Parijatah belum menyajikan laporan keuangan sesuai dengan SAK EMKM. Kendala di Silky Parijatah dalam menganalisis penyusunan laporan keuangan berdasarkan SAK EMKM yaitu sebagai berikut: Untuk penyusunan dan penyajian laporan keuangan berdasarkan SAK EMKM dimulai dari mengumpulkan bukti transaksi/pengumpulan data, penjurnalan, buku besar, neraca saldo, kemudian membuat laporan keuangan yaitu lap. posisi keuangan, lap.laba rugi, dan CALK. Laporan keuangan yang disusun oleh peneliti diSilky parijatah ini yang sesuai dengan SAK EMKM menunjukkan bahwa untuk laporan posisi keuangan menunjukkan total aset lancar Rp 2.045.527.000 dan total aset tetap Rp 1.134.665.000 jadi untuk keseluruhan total aset yang dimiliki Rp 3.180. 192.000 sedangkan untuk total kewajiban Rp Rp 1.468.809.000 dan untuk total ekuitas Rp 1.711.383.000 jadi untuk keseluruhan total kewajiban dan ekuitas Rp 3.180. 192.000. sedangkan laporan laba rugi menunjukkan total bersih $\mathrm{Rp}$ 220.543.000. Catatan atas laporan keuangan ini menyajikan gambaran umum tentang suatu perusahaan, dan pernyataan bahwa penyusunan laporan keuangan Silky Parijatah mulai tanggal 1 januari 2019 menggunakan standar yang berlaku yaitu SAK EMKM.

Untuk pihak Silky Parijatah sebaiknya mempekerjakan karyawan yang lulusan SMK atau SMA yang bisa dan faham tentang akuntansi khususnya SAK EMKM agar dapat terpenuhi, sehingga karyawan tidak melakukan pekerjaan rangkap lagi. Perusahaan sebaiknya menyadari betapa pentingnya laporan keungan untuk menilai kinerja perusahaan. Untuk penelitian yang selanjutnya dapat mencari data dari pihak lain sebagai tambahan informasi yang dapat digunakan sebagai acuan dalam pembuatan laporan keuangan yang sesuai dengan standar SAK EMKM.

\section{Daftar Rujukan}

Agus Martowardoyo, 2013, Talkshow Klaster Unggulan dan Dimensi Pola Pembiayaan UMKM di Gedung Bank Indonesia, Jakarta , diunduh tanggal 2 Oktober 2014.

Amani, T. (2018). Penerapan SAK-EMKM Sebagai Dasar Penyusunan Laporan Keuangan UMKM. ASSETS: Jurnal Ilmiah Ilmu Akuntansi, Keuangan dan Pajak, 2(2), 12-30.

Anak, Suryo. 2006. Akuntansi Untuk UKM: Metode Akuntansi Praktis dan Sederhana untuk UMK. Media Pressindo, Yogyakarta.

Arliman S, Laurensius. 2017. Perlindungan Hukum Umkm dari Eksploitasi Ekonomi dalam Rangka Peningkatan Kesejahteraan Masyarakat (UMKM Legal Protecton from Economic Exploitaton to Improve Social Welfare). Jurnal RechtsVinding, Vol. 6 No. 3, Hal. 387-402. Tersedia Pada : https://rechtsvinding.bphn.go.id/artikel/05\%20Laurensius\%20Arliman.pdf.

Bachtiar Rifa'i. 2013. Efektivitas Pemberdayaan Usaha Mikro Kecil dan Menengah (UMKM) Krupuk Ikan dalam Program Pengembangan Labsite Pemberdayaan Masyarakat Desa Kedung Rejo Kecamatan jabon Kabupaten Sidoarjo, Kebijakan dan Manajemen Publik Volume 1 nomor 1 Januari 2013 , hal 130- 136.

Bahri, Syaiful. 2016. Pengantar Akuntansi Berdasarkan SAK ETAP dan IFRS. Yogyakarta : CV. ANDI OFFSET.

Hariyono. (2010). Perencanaan Pembangunan Kota dan Perubahan Paradigma. Yogjakarta: Pustaka Pelajar.

Kieso dkk. 2007. Pengantar Akuntansi (Buku 2). Edisi 7. Salemba Empat, Jakarta.

Ningtyas, J. D. A., Si, M., \& Pusmanu, P. (2017). Penyusunan Laporan Keuangan UMKM Berdasarkan Standar Akuntansi Keuangan Entitas Mikro, Kecil dan Menengah (SAK-EMKM)(Study Kasus Di UMKM Bintang Malam Pekalongan). Politeknik Pusmanu.

Putra, Adnan Husada. 2016. Peran UMKM dalam Pembangunan dan Kesejahteraan Masyarakat Kabupaten Blora. Jurnal Analisa Sosiologi Vol. 5 No. 2 Hal. 40-52. Tersedia Pada : https://jurnal.uns.ac.id/jas/article/view/18162. 
Rahma, A. (2013). Panduan Akuntansi dan Perpajakan. Cetakan Pertama, Transmedia Pustaka, Jakarta.

Ramayani, C., Arza, F. I., \& Leries, F. V. Penerapan Standar Akuntansi Keuangan Entitas tanpa Akuntabilitas Publik (Sak Etap)(Studi Kasus pada CV. Citra Pandion Bernas di Kabupaten Solok). Pendidikan Ekonomi, 2(2).

Riswan. 2014. Analisis Laporan Keuangan Sebagai Dasar dalam Penilaian Kinerja Keuangan PT. Budi Satria Wahana Motor. Jurnal Akuntansi \& Keuangan Vol. 5, No. 1, Hal. 93-121. Tersedia Pada : http://jurnal.ubl.ac.id/index.php/jak/article/view/449.

Shonhadji, N., \& Djuwito, D. (2017, October). Penerapan Penyusunan Laporan Keuangan Pada Usaha Kecil Menengah Berdasarkan Sak Emkm Di Surabaya. In Seminar Nasional Hasil Pengabdian Kepada Masyarakat (Vol. 1, No. 1, pp. 130-136).

Suci, Yuli Rahmini. 2017. Perkembangan Umkm (Usaha Mikro Kecil dan Menengah) di Indonesia. Jurnal Ilmiah Cano Ekonomos Vol. 6 No. 1 Hal. 51-58. Tersedia Pada : http://ejournal.upp.ac.id/index.php/Cano/article/view/1239.

Sudaryanto. 2011. The Need for ICT- Education for Manager or Agribusinessman to Increasing Farm Income : Study of Factor Influences on Computer Adoption in East Java Farm Agribusiness. International Journal of Ed ucation and Development, JEDICT, Vol 7 No 1 halm. 56 67.

Sugiyono. 2014. Metode Penelitian Kuantitatif Kualitatif dan R\&D. Alfabeta, Bandung.

Sulistyo. 2010. Pengembangan Usaha Kecil dan Menengah dengan Basis Ekonomi Kerakyatan di Kabupaten Malang. Jurnal Ekonomi Modernisasi Vol. 6, No. 1, Hal. 58-73. Tersedia Pada : http://ejournal.unikama.ac.id/index.php/JEKO/article/download/31/626/.

Suryana. 2012. Ekonomi Pembangunan (Problematika dan Pendekatan). Selemba Empat, Jakarta

Suryantara, I. G. N., Kom, S., \& Kom, M. (2017). Merancang Aplikasi dengan Metodologi Extreme Programming. Elex Media Komputindo.

Tatik, T. (2018). Implementasi SAK EMKM (Standar Akuntansi Keuangan Entitas Mikro Kecil Dan Menengah) Pada Laporan Keuangan UMKM (Studi Kasus Pada UMKM XYZ Yogyakarta). Jurnal relasi stie mandala jember, 14(2), 1-14. 